\title{
TRABALLHO NEGRO, MEMÓRIA NEGRA NO VALE DO SINOS (RS): NARRAIIVA ETNOBIOGRÁFICA DE VÓ NAIR
}

\author{
Margarete Fagundes Nunes \\ Magna Lima Magalhães \\ Universidade Feevale - Brasil \\ Ana Luiza Carvalho da Rocha \\ Universidade Federal do Rio Grande do Sul - Brasil
}

Resumo: A partir da restauração da narrativa etnobiográfica de Vó Nair, 94 anos, benzedeira, que mora na cidade de Novo Hamburgo (RS), o artigo aponta para as estratégias de inserção adotadas por algumas famílias negras no mundo do trabalho na região do Vale do Rio dos Sinos. Tendo como inspiração os procedimentos de uma etnografia da duração acoplados às técnicas da etnografia sonora e visual, procuramos compreender a dinâmica da cultura urbana local e as formas de ocupação da mão de obra negra e as relações étnico-raciais presentes no interior da rítmica do mundo do trabalho na região do Vale do Sinos, situando-nos no plano da palavra viva de uma de suas principais personagens.

Palavras-chave: memória, narrativa etnobiográfica, negros, trabalho.

Abstract: Throughout the restorations of the Vó Nair, 94 years old, ethno-biografical narrative, folk-healer, who lives at Novo Hamburgo (RS) the article points out the insertion strategies that were used by some black families in the outskirts of the Sinos Valley. Inspired by the proceedings of an duration ethnography coupled with the sound and visual ethnographic technique, we look for the understanding of the local urban culture dynamics and the ways of employment of the black labour and the ethnic-racial relations that are presented within the rhythmic of the labor world in the Sinos Valley, and situating this work in a field of live testimony of one of the main characters.

Keywords: blacks, ethno-biografical narrative, labour, memory. 


\section{Introduç̃o}

Tendo como desafio o registro da presença da mão de obra de mulheres negras na composição de uma memória coletiva do mundo do trabalho no Vale do Rio dos Sinos, região historicamente importante para o estudo da contribuição dos imigrantes alemães para o processo de industrialização do Rio Grande do Sul, este artigo nasce do registro audiovisual da narrativa etnobiográfica de Nair Leopoldina de Oliveira, 94 anos, chamada por todos de Vó Nair, moradora do bairro Operário, em Novo Hamburgo. ${ }^{1}$ Vó Nair é reconhecida pela comunidade urbana local como uma benzedeira com poderes especiais; um poder que foi herdado da mãe após a sua morte e que lhe foi repassado em razão de sua posição como mulher negra, filha e neta de escravas vivendo entre as famílias alemãs na região do Vale do Sinos.

Sem abandonar a precisão do tratamento histórico ou do rigor sociológico do fenômeno da memória coletiva, nem mesmo a intransitividade de sua dimensão interior, iremos apresentar o que desponta no relato de Vó Nair acerca de seu ofício de benzedeira, isto é, os caminhos complexos que a conduziram a narrar-se a si mesma a partir das experiências de trabalho de sua avó e de sua mãe como escravas de famílias alemãs no Vale do Sinos.

\section{Remontando os fragmentos das imagens do trabalho das mulheres negras na cultura germânica no Vale do Sinos}

Esta é uma história. A minha mãe benzia. Mas benzia assim. Era nenê com costelinha pegada, era erisipela, passava a mão uma vez, duas. [...] Então a mãe foi, muita gente... Além do que ela fazia tudo. Ela benzia. Depois eu vim morar aqui. Aí eu ia de manhã trabalhar no João Hennemann, e de tarde voltava para casa. Aí a minha mãe benzia coisa pequena. Eu nem queria ver, nem queria saber. Eu passava na área a mãe tava sempre benzendo e eu nem olhava. E quando eu passava, eu via que ela passava a mão nos nenês, mas eu nem entendia o que

\footnotetext{
1 A produção desta etnobiografia é parte do material etnográfico sobre memória do trabalho de dois projetos de pesquisa em andamento: "Etnografias dos fluxos urbanos de grupos étnico-raciais em bairros de Novo Hamburgo/RS” (Universidade Feevale) e "As comunidades negras do Vale do Sinos e a memória do trabalho” (Universidade Feevale/Fapergs).
} 
ela dizia, não sabia reza, não sabia nada. Daqui a pouco minha mãe faleceu, com 105 anos, benzedeira, cozinheira, lavadeira, a mais procurada da cidade por toda a alemoada. Brigavam pela mãe. [...] Quando ela faleceu, mas antes de falecer, ela dizia pra mim "benze, benze”, falava já só com os olhos, e eu nada. Aí eu pensei: "Meu Deus, a mãe tá morrendo e me pedindo isto. Eu vou dizer que sim pra ela descansar, mas não vou fazer." Mas nem conto pra vocês, quando eu disse "tá mãe, eu vou benzer", ela se foi. Até hoje eu lembro. Mas eu pensei, vou dizer que sim, ela descansa e eu não vou fazer. Eu não lembro ao certo quanto tempo levou, mas foi pouco. Me chega uma pessoa com uma criança, pra morrer em casa. E veio aqui. Lá pelas tantas, de noite, chega aqui. Meu Deus, o que é isto? "Eu trouxe porque ele tá morrendo e a senhora vai ter que benzer o meu filho.” "Mas eu não sei!" "Tem que saber, porque sua mãe sabia.” [...] Mas eu não sabia, porque eu não escutava as rezas que a mãe fazia. Me atirou ele nos braços. Aí eu pensei: “O que eu vou fazer com esta criança?” Eu ali e a criança mal. Minha mãe tem um lavatório, uma bacia com uma jarra, e eu peguei um pano, botei em cima do lavatório e botei a criança ali. Eu sei lá, minha filha, palavra eu não tinha. Mas eu fazia assim com a mão, como a mãe fazia. Não é que a criança fez um vômito, que voou uma tira comprida, da grossura de um dedo, aquele fio comprido saindo da boquinha da criança. Salvei a criança. Botou aquilo e meu Deus do céu, o que é isto? E todo mundo ficou apavorado com aquilo. E veio pra fora. Minha mãe deve ter ajudado, não disse palavra nenhuma. E lá veio aquilo pra fora. Fui pra cozinha, fiz um chazinho ligeiro, demos de colherinha. Passamos a noite dando chazinho e no outro dia tinha salvado aquela criança, rindo, brincando. Hoje é um homem. Hoje deve estar com uns 40, 45 anos. Assim foi como começou.

No começo era apenas o relato da iniciação no ofício de benzedeira. Depois, lentamente, as estórias sobre seu oficio de benzedeira foram sendo progressivamente substituídas por recordações do trabalho de sua mãe, como escrava das principais famílias de Novo Hamburgo, e algumas passagens do que essa lhe relatara sobre sua avó, também escrava na região do Vale do Sinos. Nas idas e vindas de suas memórias sobre o trabalho das mulheres negras no interior das elites brancas locais, Vó Nair nos fez pensar acerca do que Florestan Fernandes (2007) classificou de dilema racial brasileiro. Um dilema que ainda habita as lembranças de Vó Nair sobre o processo de passagem da sua condição de escrava de estimação, na infância, para a sua condição de trabalhadora livre, na fase adulta, quando ela passou a desempenhar as funções de cozinheira, lavadeira, passadeira, além de ama-de-leite. 
Afastando-nos, assim, da nossa proposta original de registro audiovisual de sua narrativa etnobiográfica, Vó Nair, em sua sabedoria, provoca-nos a pensar as condições concretas de emergência do trabalho livre no sul do Brasil, sob o enfoque das relações interétnicas que presidiram o processo de transformação das relações de produção na economia colonial, principalmente. Por um lado, os relatos sobre as formas de trabalho que ela desempenhava no âmbito das principais famílias alemãs do Vale do Sinos nos permitem compreender como o trabalho agregado e as afiliações acabaram por preservar, no interior da cultura germânica da região, os privilégios que conformavam a antiga sociedade escravocrata e patriarcal gaúcha.

Em particular, uma pesquisa histórico-antropológica que tenha como objeto o trabalho de gerações de mulheres negras no cotidiano das famílias alemãs revela o lugar estratégico que a mão de obra de "escravas de estimação"2 ocupava na manutenção do estilo de vida e visão de mundo das elites locais, como nos informam as primeiras palavras de Vó Nair:

Ela trouxe o sobrenome... O nome era Sade Hoffmann Schmidt. Isto. O nome dos senhores, Hoffmann e Schmidt. [...] Escrava para tudo, com 6, 7 anos fazia tudo. Era mandada pra cá, pra lá, era função e laço [surra] daqui, laço dali, não fazia as coisas direito, era laço. Eu também comecei com 5, 6 aninhos. E a mãe era mandada pra tudo que era canto. [...] Naquele tempo tinha... Vocês conhecem o urinol, penico, que ficava embaixo da cama? Minha mãe tinha todo dia de manhã de recolher de todas as camas, limpar, lavar e botar no lugar, com 6, 7 aninhos. Tudo era Sade, Sade pra cá, Sade pra lá, não chamavam ela de Sara, chamavam de Sade [...].

Por outro lado, através das lembranças da passagem da infância à vida adulta, compartilhamos com Vó Nair o mundo alemão como um fenômeno plural, cultural e etnicamente multideterminado. Atentas à organicidade das camadas de duração que configuram o fenômeno temporal em detrimento de uma visão absoluta ou exclusiva - a de um tempo histórico da colonização alemã no Vale do Sinos e o tempo vivido por ela, por sua avó e sua mãe ao longo deste processo - percebemos o esforço de Vó Nair em atribuir a si mesma um valor para a sua condição social, étnica e de gênero na tradição da cultura alemã da região do Vale do Sinos.

2 Conforme expressão da baronesa E. de Langsdorff (1848 apud Moreira Leite, 1984). 
Ao agrupar seletivamente fragmentos de suas memórias como "escrava de estimação”, nos espaços privados da cultura alemã de Novo Hamburgo, em comparação a sua posterior condição de mulher negra nos espaços públicos citadinos, Vó Nair é ambivalente, pois ao mesmo tempo em que afirma que "o negro só era bom antigamente pra cozinhar, pra lavar... aí eles queriam negro”, pondera que “já bem passada a escravatura, nós já éramos bem melhor tratados pelos patrões, já não apanhava, não acontecia mais”.

Dessa forma, as memórias de Vó Nair apontam ora para o reconhecimento do trabalho de sua mãe e de sua avó, tanto quanto do seu, junto às famílias alemãs na região dos Sinos; ora para as tensões e conflitos vividos por ela e sua comunidade de origem nos espaços públicos de Novo Hamburgo, tais como os clubes, o cinema e as festas, as ruas e as praças. Seu relato sobre a presença de alguns segmentos das populações negras da cidade em espaços de sociabilidade reservados às elites locais é, nesse caso, exemplar:

E de fato, naquele tempo era um racismo que vocês nem fazem ideia. Se eu contar que eu passei partes aí do racismo, quando a gente estava mocinha, aí a gente ia ao cinema. Nós queríamos ir ao cinema, né. Nós íamos toda arrumadinha, de tope, de fita, de tênis. Quando nós chegávamos ao cinema era barrado. A gente não sentava onde os brancos sentavam. Tinha que sentar lá em cima no poleiro. Se a gente teimava em sentar, eles levavam alfinete, palito e espetavam a gente no bumbum pra gente levantar e ir lá pro poleiro. Eu passei isto. Eu cheguei a passar este tempo. Isto foi um racismo muito grande. Nós já estávamos com 15, 16 anos.

As lembranças das situações de constante discriminação étnico-racial nos espaços públicos da cidade são apaziguadas pelas lembranças da forte sociabilidade e solidariedade no interior de sua comunidade de origem, em especial, na referência às diferenças entre as territorialidades negras e alemãs em Novo Hamburgo. Uma diferença que se dilui, ao longo dos seus relatos, no momento das recordações de certas datas comemorativas, em particular aquelas cultuadas pela população negra local. Espaço e tempo singulares na vida da comunidade urbana de Novo Hamburgo, em que a "alemoada" se permitia viver no espaço público uma estratégica “mistura” étnico-racial.

É, tinha o bairro África, no Guarani, mas nós nos conhecíamos só de festa, baile, só íamos passear lá. Tudo que era negro morava lá, nós não morávamos lá. Pro lado do Mistura... Quase não tinha brasileiro até o bairro Rio Branco, era tudo alemão. Lá em cima, no Oswaldo Cruz é que começava a ter brasileiro. Rico era 
só no centro e eu tava no meio. [...] Nos momentos de festa a gente era unido. A gente só tinha esta separação. Tanto o bairro África quanto o centro nós éramos muito unidos. A minha mãe dava festa de 13 de maio. Que saudade. Era a coisa mais linda. Treze de maio não tinha separação. Os brancos festejavam com a gente o 13 de maio. Minha mãe fazia no centro. Era tudo no Rio Branco. Um lugar eu me lembro. Pra quem sai da Padaria Brasil tem um lugar que é uma casa de tapete, acho. Ali minha mãe fazia a festa. A gente de manhã acordava com foguete de 13 de maio, era dia de escravatura. Era foguete que até os brancos atiravam foguete. Os brancos faziam questão de se misturar com nós. Faziam festa até amanhecer o dia, com nós. Íamos para o centro com bandeirinhas, parecia criança [risos]. Ia a pé cantando, pulando, sambando, "Viva o 13!”, até a igreja. E o padre já estava esperando. Aí depois a negrada tava pronta pra fazer o que quisesse. As festas eram tudo ao ar livre. As melhores cozinheiras.

Momentos de celebração, quando a "negrada" - nas palavras de Vó Nair - liberta de suas funções nas casas de seus patrões invadia as ruas e praças e, em comparação às tradições das festas alemãs na região dos Sinos subvertia a ordem local, reinventando suas marcas étnicas na memória da comunidade urbana de Novo Hamburgo:

O nosso 13 era igual ao Kerb. E era respeitado. Todos os patrões liberavam as empregadas. [...] Em 13 de maio o padre abria as portas e nós entrávamos. E tinha a banda 7 de setembro, vinha tocando os hinos até chegar na igreja. Todo mundo com fita verde-amarela, vestido com babado. E nós voltávamos para o Rio Branco onde a mãe tinha o salão. $\mathrm{E}$ todos vinham comer. $\mathrm{E}$ tinha branco tirando lugar de negro pra comer. A mãe fazia aquelas mesas grandes de tábua, botava papel e aquela alemoada brigava pra ter os primeiros lugares. Aí era galinhada de um jeito ou de outro, feito pelas cozinheiras negras. Ali tinha massa feita em casa, arroz branco, cuca e pão de tarde, tudo feito pela negrada. Negrada que depois cuidava da casa deles [risos]. Era bonito ver aquela gente rica misturada com a gente. Antes era aquele racismo. Tinha racismo pra ir numa praça sentar num banco.

No caso específico do relato etnobiográfico ${ }^{3}$ de Vó Nair, a integração da força de trabalho escrava de mulheres negras (escravas africanas e suas filhas

3 A respeito do termo “etnobiográfico" seguimos a proposta conceitual que orienta o cinema documental de Jorge Prelorán (1987). 
e netas "mulatas" ou "pardas") não decorre da simples valoração negativa dos ofícios manuais e braçais desempenhados por elas, mas pela quase ausência de referência a essa mão de obra no mundo do trabalho do Vale do Sinos, em especial, no interior das elites locais.

Quando me lembro, parece mentira que a gente fazia isto. Lembro mas parece mentira, nossa! Era nossa vida, sempre lavando roupa. A mãe tinha o São Jacó e o Santa Catarina [colégios]. Então, pra todas estas internadas a mãe é que lavava. Aí a gente morava ali, no meio dos alemães. Era só nós que ficava ali, anos e anos no meio dos alemães. Mas porque a gente falava alemão, a gente se dava bem.

É evidente, portanto, que a referência das rememorações do mundo do trabalho em Novo Hamburgo e do processo migratório dos alemães para a região do Vale do Sinos traz a singularidade das relações entre brancos e negros na cidade de Novo Hamburgo. A separação rígida do mundo dos brancos e dos negros não ocorria apenas às portas fechadas dos estabelecimentos e instituições, ampliava-se para as formas de ocupação dos espaços públicos de Novo Hamburgo e se diluía em complexas relações no interior da vida cotidiana das famílias das aristocracias locais.

A gente só era bem aceito, bem recebido, dentro dos bares e nestes lugares assim quando era carnaval. Aí eles queriam ver os negros. Aí eles davam cerveja, bebida, davam tudo pra gente fazer o carnaval lá na frente deles. Ali no centro, onde hoje é a Rainha das Noivas, ali na frente da Rainha das Noivas era o bar do Paulo Hoffmeister, parece. Ali eles chamavam a gente, lá pra dentro pra servir bebida e tudo, só por causa do carnaval. A gente sambando, pulando, eles adoravam isto. Mas era só. Dali por diante a gente era a negrada de novo. [...] Uma ocasião nós fomos pra praça e sentamos no banco da praça. Acredita que eles fizeram a gente levantar. Se havia um alemão sentado e a gente sentava, ou ele não deixava ou ele levantava e ia embora, saía dali.

Para se compreender a força simbólica que subjaz no relato de Vó Nair acerca da presença da mão de obra escrava de mulheres negras na memória coletiva da cultura germânica (aqui, no caso, de escrava de estimação à benzedeira), vale a pena uma visita às diferentes narrativas historiográficas que sustentam o mito fundacional da imigração alemã no Vale do Sinos e sua associação à inserção da mão de obra livre no Rio Grande do Sul. Um mito de 
origem relacionado às formas de violência que compuseram a organização do trabalho dos imigrantes no interior do modus vivendi da sociedade escravocrata e patriarcal do Brasil Império.

Acompanhar os jogos da memória de Vó Nair significa, portanto, reconhecer a inteligência narrativa (Eckert; Rocha, 2005) por meio da qual ela acomoda as rememorações do seu atual ofício de bendezeira, em alusão à ancestralidade dos trabalhos de sua mãe como escrava na região do Vale do Sinos, assim como a aprendizagem do dialeto alemão com o qual ela se comunicava fluentemente com seus patrões, passando pelo legado que deixa para as famílias alemãs mais tradicionais de Novo Hamburgo, no exercício de seu ofício de empregada doméstica.

Segundo apontam alguns autores (Tramontini, 1997; Zubaran, 1994), os ideólogos da identidade étnica dos imigrantes teutos no sul do Brasil insistem em afirmar que os imigrantes/colonos não tinham escravos uma vez que a cultura germânica valorizava, desde suas origens, o trabalho livre, distanciando-se, assim, os imigrantes/colonos da bárbara prática luso-brasileira (Müller, 1998), a do trabalho escravo.

As razões para esse mito fundacional do imigrante alemão são muitas, mas poderiam ser condensadas em duas perspectivas. A primeira considera a inexistência de escravos entre os teuto-brasileiros por serem eles pequenos proprietários de uma agricultura de policultura, tendo por base uma economia familiar que prescindiria, portanto, da mão de obra escrava. A segunda sustenta que a cultura germânica se caracterizaria por uma ética do trabalho que, por suas origens, contrastaria com a mentalidade luso-colonialista e escravista. Maria Angélica Zubaran (1994) reconhece uma terceira perspectiva com a qual as duas outras travam um diálogo constante, ou seja, as leis provinciais e imperiais impediriam aos teuto-rio-grandenses o uso da mão de obra escrava.

Mais precisamente, sob a ótica do mito do progresso derivado do mito histórico, a força moral do trabalho livre do colono alemão que se implantava no sul do Brasil, durante o governo imperial, teria sido capaz de apagar, finalmente, os vestígios da presença da mão de obra negra, escrava, pelo governo imperial na região. ${ }^{4} \mathrm{O}$ trabalho livre enquanto valor não apenas revelaria a

4 Para o aprofundamento dessa discussão, ver a tese de doutorado de Nunes (2009). 
identidade étnica no Vale do Sinos, por oposição ao trabalho escravo da cultura luso-brasileira, mas se articularia a outro mito fundacional da presença dos alemães na região do Rio dos Sinos, o mito da abundância, em contraste com as imagens da ruína e da escassez associadas à presença do complexo cultural dos latifúndios e das fazendas no sul do Brasil.

Sob a perspectiva das memórias do cotidiano que configuram a etnobiografia do trabalho de Vó Nair, e que remontam à geração de sua avó e de sua mãe, a prática da escravidão acompanhou as formas de organização da produção no interior das colônias alemãs na região dos Sinos, indicando que os teutos e seus descendentes conviviam com um sistema escravocrata e patriarcal sendo, entretanto, quando no caso do uso da mão de obra escrava, "bons senhores, sem infligir-lhes maus tratos" (Zubaran, 1994).

Um fenômeno visível na composição da trajetória social de Vó Nair na sua referência às estórias de violência sofridas por sua mãe na condição de escrava de estimação:

Ela contou muitas histórias, muitas mesmo, onde ela contou uma que era pra apanhar e ela se escondeu embaixo da cama. E não achavam ela. Aí disseram: "Vamos pegar o relho, quando ela chegar vamos dar de relho nela." Ela ouviu e saiu ligeiro gritando "eu tô aqui, eu tô aqui" [fala em alemão]. E ela dizia tô aqui, já venho, e dentro de casa. Aí eles pegaram o relho e deram nela. Acertaram na cabeça. Ficou um vinco da grossura de um dedo, aquele vinco da argola. Ela contou muitas coisas que ela passou. Aquilo tudo em alemão. [...] E assim foi indo a vida dela, apanhando, fazendo serviço. Outro dia ela cansou e disse, eu vou me atirar aqui dentro. Tinha uma cisterna, um lugar onde se guarda água da chuva. $E$ aquilo era do tamanho de uma peça de uma casa. Até aqui na esquina tinha uma cisterna de água, a CEE puxava água do arroio pra cá. E assim a mãe disse, eu vou me atirar aqui dentro. Quando ela foi pra se atirar, ela vê lá dentro, no fundo, a imagem dela. Sabe que ela voltou pra trás. Diz que deu um pavor nela, voltou pra trás correndo. Não se lembrou mais nem do relho, da surra que tinha que levar. “Onde é que tu tava Sade?”, perguntaram. Ela tava perto da casa, mas não viram ela porque não foram para aquele lado.

Segundo Tramontini (1997), não se pode refletir sobre o trabalho livre dos imigrantes alemães, em suas articulações com o trabalho escravo na região dos Sinos, sem abordar as dificuldades do sistema econômico e político imperial escravista do sul do Brasil, especialmente, em absorver esta população 
livre, pobre e estrangeira, considerando-se sua grande capacidade de organização social para ocupar espaços na estrutura social e política brasileira.

As relações de poder unindo "negros" e "brancos", alemães e "brasileiros" ao mundo da produção de Novo Hamburgo, destacam-se em outras narrativas que explicitam a continuidade dos valores da "velha ordem social" escravocrata e racista no interior do mundo do trabalho livre (Fernandes, 2007). E, nestes termos, a forma de organização social e política que orientou o mundo do trabalho dos imigrantes alemães no Vale do Sinos implicou a articulação das famílias com as facções sociais e políticas locais, além da rápida incorporação de práticas locais tais como o apossamento de terras e a escravidão (Tramontini, 1997).

\section{Restaurando imagens da escravidão nas origens da moderna cultura germânica}

É evidente que as famílias alemãs se depararam com a presença negra e a escravidão, marcas fundamentais da dinâmica histórica do processo civilizacional no sul do Brasil, desde o início da ocupação do território, assim como em outras regiões, seja como mão de obra nas fazendas e nas milícias das oligarquias pecuaristas, seja na produção agrícola implantada pelas famílias açorianas ao longo de todo o século XIX, ou ainda, nas charqueadas. ${ }^{5}$ Em todo o caso, é relevante para este artigo pensar o contato da cultura alemã com as práticas locais da escravidão na região dos Sinos, não apenas como resultado da experiência da migração europeia no sul do Brasil, como assinalado anteriormente, mas também como parte de uma relação arcaica dos imigrantes com o tema do negro e da escravidão na sua cultura de origem.

Ao contrário do que se poderia pensar, o confronto da cultura germânica com o processo de escravidão não deriva do contato dos imigrantes alemães em terras brasileiras, mas conforma parte da memória coletiva que orienta a formação dos próprios estados alemães nos primórdios dos tempos modernos.

\footnotetext{
Conforme apontam estudos clássicos do trabalho escravo nas charqueadas (Cardoso, 1977) como parte do processo de implantação de uma civilização urbana no Brasil meridional, em especial, a produção do charque promoveu a formação de fortunas e a prosperidade de algumas cidades, sendo a responsável pelo incremento do uso da mão de obra escrava tanto para trabalhos domésticos quanto artesanais e "serviços”, com a cidade de Rio Grande destacando-se, em meados do século XIX, como um dos principais polos do comércio negreiro do Império Brasileiro.
}

Horizontes Antropológicos, Porto Alegre, ano 19, n. 39, p. 269-292, jan./jun. 2013 
Não apenas nos países de cultura germânica, mas em muitos outros países europeus no início da era moderna, inúmeros africanos e ex-escravos oriundos das Américas conviviam com famílias aristocráticas ou com ricas famílias burguesas, na condição de empregados domésticos, e cuja forma elaborada de seus modos de vestir expressavam a importância e a riqueza das pessoas para as quais eles trabalhavam. Negros igualmente submetidos a relações de propriedade, os quais, diferentemente do que ocorria no mundo colonial, podiam se movimentar com certa autonomia dentro da sociedade branca (Lind, 2001). A conversão dos escravos à fé cristã desempenhava, por sua vez, um papel fundamental na integração dos negros na sociedade alemã, os quais adotavam, após o rito de passagem, o nome de seus padrinhos, geralmente duques, aristocratas, altos oficiais militares etc. (Lind, 2001). Por outro lado, na sociedade altamente estratificada e hierárquica que configurava a Alemanha dos primórdios da era moderna, assim como nas colônias de outros países europeus, os casamentos entre negros e brancos eram geralmente indesejáveis.

Apesar da presença inexpressiva dos alemães no tráfico mundial de escravos e das raras expedições científicas em terras estrangeiras subsidiadas por estados alemães, a convivialidade da cultura germânica com o tema da escravidão transparece na arte, na literatura e no debate público (Lind, 2001). ${ }^{6}$ É na ótica da "pedagogia das imagens” (Durand, 1984) que se configura a cultura germânica dos primórdios da modernidade, e não é raro o culto ao exotismo do negro africano e a aceitação de sua condição de dependência privilegiada, aparecendo a figura do escravo com relativa frequência sempre posicionada como mão de obra no interior das famílias aristocráticas da época.

Da mesma forma, o tema da escravidão (Lind, 2001) aparece nas reflexões dos pensadores iluministas alemães (cientistas e filósofos), os quais vão seguir de perto o desenvolvimento do debate sobre a definição da natureza e da história dos seres humanos, na intenção de definir e classificar

6 Em seu estudo Vera Lind (2001) ressalta que a figura do negro africano despontava, na época, como um dos motivos favoritos para decorar porcelanas, relógios e pinturas, e que as silhuetas de africanos apareciam nos brasões de várias cidades alemãs, sendo os negros personagens populares em romances, poemas e peças teatrais. 
as diferenças entre sociedades patriarcais e escravocratas em outros países europeus e no exterior. ${ }^{7}$

Em decorrência destes breves apontamentos, poderíamos supor que a ausência da mão de obra escrava nas colônias alemãs no Vale do Sinos, como parte da tradição germânica do trabalho livre na região, resultaria num arranjo específico das formas de organizações do mundo do trabalho das famílias negras entre os colonos alemães em contraposição às dos "brasileiros”. Um fenômeno que acompanharia a configuração do mito fundacional do homem livre pobre "nacional” como parte dos esforços das famílias alemãs para conquistar espaços no interior das oligarquias locais (o direito de posse da terra, de votar e ser votado, de possuir escravos, etc.). Entretanto, os relatos de Vó Nair e as lembranças das estórias contadas por sua mãe, dela e de sua avó, ambas como "escravas de estimação", nos conduzem a explorar muitas outras fontes documentais históricas que evidenciam o emprego da mão de obra escrava entre os colonos alemães.

Minha história veio da minha mãe. A minha mãe era da serra, Dois Irmãos. Ela era filha de escravo, então quando a minha avó foi mandada para Porto Alegre por um dos filhos dos senhores dela, foi mandada para Porto Alegre com um filho que casou, e minha mãe com 5 ou 6 aninhos, e arrancaram dos braços da minha avó e ficaram com a negrinha, lá, os velhos, os senhores. E a minha avó foi com o filho dos senhores para Porto Alegre e ali ela ficou escravinha. Ela veio morar ali nos Zott. Eles foram donos dos primeiros ônibus e caminhões de Novo Hamburgo. Era Hamburgo Velho, na Vila Nova. Ali, eles foram morar. A mãe e o pai. Ali eles foram... Depois que o pai morreu a minha mãe veio para Novo Hamburgo.

Em particular, aparece o emprego da mão de obra escrava nas mais diversas atividades artesanais, além de uma variação considerável de tipos de vínculos de trabalho como domésticas no interior das famílias, como agregadas,

\footnotetext{
Conforme Vera Lind (2001), muitas pinturas do século XVIII são retratos de grupo de uma família ou filhos, ou retratos de aristocratas, imperadores, duques, duquesas, e assim por diante, acompanhados por um empregado negro. Por um lado, as pessoas negras são partes de cenas quase íntimas, mostrando a sua proximidade com o patrocinador e a estima em que são realizadas. Por outro lado, a pessoa preta é usada como um exótico símbolo de riqueza. Algumas pinturas, em particular as que retratam aristocráticas mulheres brancas com seus empregados negros, claramente envolvem conotações sexuais. Em outras, o esquema de cores da pintura enfatiza o contraste entre cor de pele preta e branca no encontro entre africanos e alemães, claramente desenvolvido ao longo de linhas diferentes do que em outros países dentro do sistema Atlântico.
} 
sendo, entretanto, essa mão de obra regulada, em sua maioria, pelo uso de castigos físicos, ${ }^{8}$ na linha dos relatos de Vó Nair e de suas memórias de família, ao invés de pretensa "escravidão respeitosa". ${ }^{9}$

\section{Os vestígios do mundo escravo na inserção da mulher negra no mercado de trabalho livre}

Considerando a evidência do trabalho escravo como integrante da cultura germânica no Vale do Sinos, prosseguimos nos relatos de Vó Nair sobre sua trajetória de escrava de estimação à empregada doméstica e, logo após, com a morte de sua mãe, como benzedeira, indagando-nos sobre o processo de inserção social vivido por ela no mundo do trabalho livre em Novo Hamburgo. Nesse ponto, torna-se relevante compreender, na linha de outros estudos (Giacomini, 1988; Souza, 1982, Vieira, 1987), como as memórias do trabalho de Vó Nair nos possibilitam pensar a forma que as mulheres negras, nascidas de mães escravas, realizaram a passagem à condição de empregada doméstica, cujas atividades, ao longo do século XX, vão sendo progressivamente reguladas e formalizadas.

No caso do relato de Vó Nair notamos que o mundo do trabalho da doméstica, antes de ser visto na perspectiva de um sistema de transmissão de saberes e fazeres entre gerações de mulheres trabalhadoras, carrega consigo a marca do poder e da exploração de uma sociedade patriarcal, obviamente segundo suas transformações ao longo de tempos e espaços determinados.

8 Conforme Tramontini (1997), os colonos alemães aparecem com bastante frequência como compradores ou locatários de negros para auxiliar na agricultura. Segundo o autor, o primeiro código de postura de São Leopoldo (1848) incluía uma cláusula, por exemplo, que proibia aos senhores castigarem seus escravos após as 20 horas, no inverno, e 21 horas, no verão, para não incomodar a vizinhança com os barulhos. Logo após, em 1850, o Dr. João Daniel Hillebrand, comandante da povoação de São Leopoldo, líder dos colonos alinhados com as forças liberais, comunica ao presidente da província, após o fim da Revolução Farroupilha, que a escravatura "teve pouco aumento, constando apenas na região 229 escravos".

9 Segundo depoimento de Von Hoffman (1934 apud Tramontini, 2000, p. 1), retirado do livro Nach Brasilien und zurück in die Heimat, de 1878, no trecho em que afirma que os negros eram bem tratados pelos alemães, que podiam no seu tempo livre vender doces, água ou bananas nas ruas. Tinham também o direito a um baile de negros de vez em quando. E, aos domingos, se viam muitas escravas passeando "tão bem arrumadas que nem pareciam sê-lo", com vestidos de seda, colares de pérola, brincos, cabelos repartidos e arrumados e sombrinhas. Acrescentando que boa parte dos negros falava o dialeto alemão da família onde trabalhava.

Horizontes Antropológicos, Porto Alegre, ano 19, n. 39, p. 269-292, jan./jun. 2013 
Um fenômeno que não é singular, uma vez que encontra ressonância em outros estudos sobre a travessia realizada pela mulher negra até o emprego doméstico ao longo do século XX (Lima Ribeiro, 1943; Pinto, 2012; Saffioti, 1978).

As marcas do poder escravocrata e patriarcal revelam-se, no caso de Vó Nair, em certo apagamento da violência que presidiu a sua vida de trabalho na região dos Sinos. Foram poucos os momentos em que Vó Nair explicitou a dura experiência vivida pelas mulheres de sua família entre as famílias alemãs de Novo Hamburgo.

Dava mais ou menos, o ponto mais ou menos onde tem aquele negócio de comer frios, passava a ponte, do lado esquerdo tem um xis, onde fica cheio de carro, tem o colégio Pio XII, tem o Pica-Pau. Então naquele rio a gente vinha lavar roupa. A mãe lavava, nós já ajudávamos. Tirava a roupa que era pra quarar, era tudo grama, atirava pra cima, nós já ia estendendo no quadro. Nós já estendíamos o que era pra torcer ela atirava pra cima, o arroio lá no fundo. Quando a gente tinha uma folguinha, a gente pegava o anzol, uma varinha, botava o anzol, ali se lavava roupa, ali se pescava, ali se fritava e comia. A mãe torcia roupa, tinha assim uns tijolos e minha mãe levava umas latas para ferver a roupa, naquele tempo se fervia a roupa, atirava tudo pra cima, e ela lá, no fundo, lavando e atirando o que era pra quarar, o que era pra ferver, o que era pra estender. E nós fizemos aquele trabalho lá em cima, né. E quando a gente tinha uma folguinha a gente ia e pescava ali. A gente pescava lambari.

No momento de atribuir a sua competência nos afazeres domésticos, tais como limpar a casa, cozinhar, lavar e passar roupa, etc. é constante a referência de Vó Nair à sua atuação como doméstica associada à formação obtida junto à sua patroa. Raros foram os momentos em que ela atribuiu suas competências no exercício dos ofícios do trabalho doméstico como parte do legado de trabalho de sua mãe:

E então a minha mãe, na época, ela começou a ser e era, já veio de lá dos primeiros donos dela né, ela já veio sabendo cozinhar, sabendo lavar, sabendo fazer tudo. E assim ela começou a trabalhar para criar a negradinha toda. Era uma família grande a da mãe. Eram uns 10 filhos. E aí fomos morar ali numa casa. Ficava ali naquele triângulo que tem no bairro Rio Branco, depois da Padaria Brasil. Tem um triângulo de motorista, ali era a nossa casa. A primeira casa bem no meio da alemoada toda [risos]. E não tinha diferença porque nós falávamos tudo alemão. Aí a gente foi morar ali. Ela lavava roupa, ela passava roupa, era cozinheira, era arrumadeira, ela era lavadeira de roupa no arroio. Lavava roupas 
para os colégios. Antigamente, o São Jacó tinha criança hospedada, como se dizia, internos, lá no colégio São Jacó. Esta gurizada interna vinha de todo lugar, eram internados ali. Era a minha mãe que lavava as roupas. Então vinha tudo em saquinhos. E nós já ajudávamos a mãe a trazer roupa pra lavar aqui neste arroio onde vão mexer agora, vai passar ali o negócio do Trensurb. Então ali na ponte. Ali a gente lavava roupa. Água limpinha. Ali se lavava roupa o dia todo, né.

Logo, é importante ressaltar que a compreensão dos processos de exploração da mão de obra das populações negras no mercado de trabalho da sociedade brasileira não se situa, simplesmente, no sistema escravocrata, mas acompanha a transição do trabalho escravo para o trabalho livre. Nas palavras de Vó Nair, essa transição aparece associada a novas formas de arranjo de sua mão de obra no interior da organização do mundo do trabalho em Novo Hamburgo e às alterações nos estilos de vida das famílias alemãs:

Mas eu passei uma época de racismo muito grande. Interessante foi quando eu fui trabalhar. Eu estava com 6 anos. Eu fui trabalhar no Alvício Klaser, Foi o maior industrialista de Novo Hamburgo. Na época, eram três irmãos, aí eu fui trabalhar ali, de babá. Comecei a trabalhar ali. Nós morávamos do outro lado da rua e eles na esquina da mesma rua. Era mais ou menos meia quadra que a mãe morava da casa do Alvício. E, naquele tempo, a sogra do Alvício fazia pão pra Novo Hamburgo. Fazia pão pra uma imensidade de gente, a sogra do Alvício Klaser.

Da mesma forma, fica evidente que a passagem do trabalho escravo para o livre e assalariado incorpora as bases racistas da antiga ordem patriarcal da sociedade brasileira, através da construção de narrativas sobre a inferioridade do negro para justificar a sua exclusão do mercado de trabalho (Azevedo, 1985). Uma condição visível na forma como aparece no relato de Vó Nair o ordenamento das lembranças de sua vida de trabalho em Novo Hamburgo, antes de sua ocupação de benzedeira no interior das famílias locais.

Foi assim, uma vida muito gozada a nossa. E depois foi assim, ficamos muito tempo conhecidos, Novo Hamburgo era os Lara pra tudo, pra tudo, pra tudo era os Lara né. A gente ficou conhecida, conhecidíssima. Dar de mamar, a minha mãe deu de mamar. Três eu ainda lembro, ela deu de mamar pra três prefeitos de Novo Hamburgo. Ela deu mama pro Koch, tem outro, ela deu mama pra cada alemãozinho que nascia, que a mãe tinha um negrinho junto, tudo mamou na mãe. Sei que naquele tempo as mães brancas não tinham leite, não ganhavam leite, sei lá. 
Interessante perceber que, na época, a passagem de Sade, mãe de Vó Nair, da condição de "escrava de estimação” para a de ama de leite e de empregada doméstica, assalariada, dedicada à criação dos filhos das elites locais, confrontava claramente o próprio código de posturas vigente em fins do século XIX, em Novo Hamburgo. Tal código de posturas - fortemente influenciado pela propagação do eugenismo na sociedade brasileira - orientava as famílias no sentido de abandonar os antigos hábitos de uma sociedade patriarcal e escravocrata que conformavam o trabalho dos criados de servir e das amas de leite. Além disso, segundo as práticas da medicina, as famílias eram aconselhadas a não manterem em suas casas, sob o mesmo teto, as escravas domésticas e a não deixarem a essas os cuidados das amas de leite, em especial, a amamentação de seus filhos. No entanto, a lista de nomes citados por Vó Nair é extensa e precisa:

Então tem muito alemão que mamou na minha mãe, junto com cada negrinho que ela tinha. Tinha os Scherer, tinha o Armando Koch que foi prefeito, um Adams mamou na minha mãe. Tinha mais um que era meio brasileiro. Mas a maioria naquela época a mãe tinha um filho, sempre tinha um alemãozinho junto. E tinha um alemãozinho que era o Scherer, o Scherer ficou tão agarrado com a mãe que quando ela colocava meu irmãozinho pra mamar junto com ele, ele empurrava o negrinho. A mãe passava um trabalho na hora que botava o Scherer com um dos meus irmãos que era uma barbaridade.

Portanto, ao nos determos na vida cotidiana das populações negras no interior das famílias alemãs, percebemos que o código de posturas de Novo Hamburgo não era seguido à risca, uma vez que ele previa que todo indivíduo que quisesse exercer o trabalho dos criados de servir e das amas de leite deveria inscrever-se no Livro de Registros da Secretaria da Polícia, atestando ser a pessoa abonada e livre, estando sujeita, em caso contrário, a pena de multa ou prisão. ${ }^{10}$

${ }^{10}$ Conforme os relatos apresentados por Giacomini (1988, p. 22): “Como amigo dos nossos patrícios e interessado na paz das famílias da nossa terra, não devemos deixar de aconselhar-lhes que substituam, ou ao menos que diminuam o número desses muitos inimigos que se nutrem em nosso seio. Criados livres, morigerados e bons, como os que podemos encontrar entre as famílias alemãs que emigram para as nossas praias, são os que ora nos convém para, não só resguardarmos do perigo que nos está eminente, como também nos fora da influência danosa que sobre nós tem produzido os escravos.”

Horizontes Antropológicos, Porto Alegre, ano 19, n. 39, p. 269-292, jan./jun. 2013 
No caso de Vó Nair, fica evidente que sua entrada no mercado de trabalho livre como doméstica, no interior das famílias das classes mais abonadas e brancas da cidade, foi diferenciada em relação à trajetória social de sua mãe, Sade, e à de sua avó.

Eu nasci em Hamburgo Velho, vim parar aqui. [...] Depois do Alvício Klaser, que eu fiquei seis anos, [...] a mãe foi convidada a trabalhar em uma chácara em Porto Alegre, chácara dos... não lembro o nome. Sei que esta chácara era lá onde passa o rio, Pedras Brancas, não, era Tristeza. Ali tinha uma chácara de um senhor que agora não me lembro do nome, e ali a mãe foi morar. Nós fomos juntos, nós éramos quatro negrinhos, eu, uma sobrinha, outro sobrinho e mais uma sobrinha. A mãe tava criando três netos e eu junto. E aí fomos pra lá. Mal nós estávamos lá, uma semana ou duas, a minha tia de Porto Alegre, tios por parte de pai moravam tudo em POA. Eles arrumaram serviço pra mim, e neste serviço eu fui pra casa do senhor Raul Bitencourt. Esse doutor Raul Bitencourt, ele era médico do hospício São Pedro. Ele era deputado estadual, e eu fiquei na casa deles, daquela idade em diante. Eu fui até pro Rio de Janeiro com esta gente.[...] Eu sou de 1918. Foi a Revolução de 30 acho. E com aquilo o meu patrão Raul teve que ir para o Rio. Chegou lá, mandou chamar a família com os dois filhos, eu era a babá dos dois filhos. A senhora nem imagina, a vida que eu tinha com esta família no Rio de Janeiro. E a minha mãe disse, vocês levem esta negrinha e me tragam ela de volta, não me deixem esta negrinha por lá. E fizeram. Me cuidaram direitinho. Eu fui ama-seca, e eles podre de rico. Ali tinha lavadeira, passadeira, cozinheira, tinha arrumadeira, empregada pra tudo. Não precisei mais do banquinho. Andava toda engomadinha, de topinho, rendinha, vinha tudo prontinho pra mim. Nós acordávamos de manhã, se arrumava e bum pra rua.

Podemos pensar que a trajetória dessas gerações de mulheres negras é diferenciada em relação a de outras mulheres de sua comunidade de origem em razão do domínio que tinham do dialeto alemão, que permitia maior diálogo com suas patroas e com suas proles. Em especial, a etnobiografia de Vó Nair nos apresenta o domínio do dialeto alemão como elemento estrutural da inserção das mulheres de sua família, pela linhagem de sua avó escrava, ao longo de gerações, como agregados das famílias tradicionais do Vale do Sinos. Nas palavras de Vó Nair:

Novo Hamburgo, naquele tempo, era... Onde a mãe foi morar chamava-se Mistura. Da ponte pra lá era Mistura, o nome que deram assim. E ali era tudo quase só alemão. E nós fomos de muda pra ali, no meio daquela alemoada toda. 
[...] Mas a minha mãe já falava alemão. Nós já falávamos alemão. Depois que a mãe casou com pai, todos nós falávamos alemão. E aí fomos morar ali. Então aquela gente dali, reparava, olhava.[...] A minha mãe foi a única que se tornou conhecidíssima dentro de Novo Hamburgo, de preta, era minha mãe. Ela fazia todo este serviço, ela cozinhava pra fora, ela cozinhava nos Kerb, ela cozinhava nas festas dos alemães tudo. Era casamento era tudo. Ela foi dos Mosmman, ela foi cozinheira dos velhos Mosmman. Dali em diante a mãe fazia todos os batizados, as festas de batizado, de comunhão. Ela fez a festa de todos os Mosmman. Agora faz uma ideia, era uns cinco ou seis, ainda tem aí os das construtoras, tem aquele que tem a Macosan. Isto tudo é como filho da mãe. São todos assim, se tem como filhos.

Entretanto, ainda que diferenciada, nas palavras de Vó Nair permanece a referência à situação de discriminação racial vivida de forma similar a outras tantas mulheres negras no Brasil (Barros, 1985):

Ali na casa do Alvício tinha que fazer mamadeira pras crianças, tinha que lavar roupinha, tinha que passar. Tudo isso eu fazia. Mas eu não tinha assim é tempo pra nada. Até mesmo pra estudar, porque o colégio também era na mesma rua. Essa rua que passa atrás da Cavasotto, que só vai pra cima, ali na Padaria Brasil. Então lavar louça, tudo isto, eu já tava ali com meus 8 [anos] e até então a gente passava, fazia tudo o que tinha que fazer lá embaixo e aí subia. Tinha uns degrauzinhos pra subir [...].

Diante dos processos de discriminação vividos na relação entre empregadas e patrões, a expectativa era que a passagem da condição de escrava de estimação para a de empregada doméstica se configurasse na possibilidade de encontrar bons patrões, ou seja, que se lhe fizessem concessões e a tratassem como "pessoa".

[...] o Alvício chegava em casa tava eu fazendo mamadeira ou passando roupa, fazendo servicinho, né. [...] Ele disse: "Mas esta criança, isto é uma criança. Eu vou fazer um banquinho pra ela andar com este banquinho." Aí ele fez um banquinho pra mim poder passar roupa, pra mim poder ir pro tanque lavar roupa. Eu tinha um banquinho de dois pés, mas era pé firme. Uma tábua em cima desta alturinha pra mim carregar aonde eu ia. Pro tanque eu carregava o banquinho, pra poder lavar roupa eu levava o banquinho, pra poder passar roupa eu levava o banquinho, levava o banquinho e fazendo as mamadeiras e as crianças eu 
carregava [...]. Aqui, eu sou um pouco torta de carregar eles enganchando assim [mostra a cintura] [...].

Ao pensarmos as relações de trabalho que uniam as gerações de mulheres da família de Vó Nair ao percurso de inúmeras famílias alemãs, pertencentes à aristocracia local, percebemos a condição de agregada que ela veio a ocupar na estrutura familiar das suas patroas, nos moldes descritos por José de Souza Martins (1979) em seus estudos:

Como nós morávamos perto, e eu empregadinha na casa do Alvício, eu saía de manhã cedo de casa, passava na velha sogra, a velha sogra fazia pão pra fora. Ali tinha umas 20, 30, 40 latinhas de pão. Era tudo como hoje, tem as garrafinhas de azeite, as latinhas de azeite. Então era um forno enorme, mas os fornos estavam em cima de uma mesa, numa prateleira, e ela botava dentro das latinhas banha pra passar nas forminhas pra untar pão. [...] Imagina, eu saía dali de casa, passava na casa da velha, passava azeite naquelas latinhas tudo, e já atravessava a rua pra ir cuidar dos filhos do Alvício que eram netinhos dela. Imagina, 6, 7, 8 anos, né. E aí fazia tudo aquilo tudo e ia pra casa do Alvício.

\section{A presença do cativeiro na passagem de "escrava de estimação" a de empregada doméstica: à guisa de conclusão}

Um aspecto visível no relato etnográfico de Vó Nair diz respeito às formas das trocas sociais que ela estabelecia com seus patrões, regidas basicamente na aceitação e reconhecimento da autoridade dos valores ético-morais característicos da antiga sociedade patriarcal e escravocrata.

Sei lá. Dava tempo pra tudo. Aí nós morávamos atrás da igreja. Tinha uma casinha pequeninha, uma maloquinha, que depois de casada eu fui pra ali, fui morar ali atrás da igreja, onde hoje tem aquelas butiques da Magda. Ali onde é aquelas lojas era a casa da minha mãe. E a minha mãe trabalhava para os Becker. Nós e os Becker moramos ali onde hoje tem as lojas. [...] Que história que eu estou contando para vocês. Tô começando a me recordar. Aí os Becker foram vendendo onde está as lojas hoje. A Magda é como filha pra mim e eu como mãe pra ela. [...] Ali eu casei. Ali que eu fui morar. Sabe que ficamos muitos anos ali. Pois é. Era eu, a mãe, um irmão meu, o Chimia, o maior motorista de Novo Hamburgo. 
Ficou trabalhando no João Hennemann. Foi o primeiro que ensinou as mulheres brancas. Ficou Chimia por causa daquela alemoada toda. Dali eu saí casada.

Sob esse aspecto, o local de residência estrategicamente próximo ao local de moradia das famílias nas quais ela trabalhava, desde a tenra idade, vai se perpetuar ao longo de toda a sua vida como doméstica, acompanhando por gerações e gerações os seus descendentes. Uma forma dos seus patrões permitirem a essas mulheres, seus filhos e maridos a produção direta dos meios de vida necessários à reprodução da sua força de trabalho.

Ali onde é o restaurante foi onde me empreguei na casa do Hennemann. [...] Aí eu fui passando de um irmão para o outro dos Hennemann. [...] Ali tinha gêmeos. Ali eu fiquei muito tempo. Quando os gêmeos vieram, eu já estava lá há tempo. Eu fiquei 27 anos na casa do João Hennemann. [...] Sei lá se é dizer que passei trabalho. [...] Vi os filhos dele crescer, casar. O último que eu vi foi o da Marta que casou com o filho do Klaser.

Para a Vó Nair, em sua condição de empregada doméstica, a autoridade dos patrões brancos relacionava-se ao nível educacional, econômico e social que lhes auferia um poder irreal, forte o suficiente para interferir na sua privacidade e intimidade:

E aí então a gente morava naquela rua. Nós, o Alvício Klaser... A professora também era daquela rua. E aí então, de tarde, eu ia pro colégio. Pensa que eu ficava uma hora inteira? Os alemãezinhos tudo na mesma rua [...]. A professora tinha que me largar pra eu ir brincar com eles, podia estudar? De maneira nenhuma. Ela me largava pra eu ir brincar com as crianças, fechava a porta e eu ficava brincando na rua. Olha, não estudei nada, nem sei que livro que eu fiz, sei lá. Acho que só o primeiro livro. Tabuada a gente lia, escrever, isto aí eu aprendi muito pouco no colégio, porque as crianças não me deixavam.

Nesses termos, o trabalho livre na condição de agregado das famílias alemãs, que era o caso de Vó Nair e de sua mãe Sade, diferia do trabalho escravo exercido por sua mãe e avó "na medida em que se baseava na separação do trabalhador de sua força de trabalho e nela se fundava a sujeição ao capital personificado pela propriedade fundiária”, aqui no caso das famílias alemãs (Souza Martins, 1979, p. 12). 
Fui pra casa do Klaser, mas viúva, mas eu fiquei pouco tempo. Aí quem me pegou foi o João Hennemann. Ali onde é o edifício da Livraria Flama, era a casa do João Hennemann. Aquele edifício todo, até o outro edifício, aquela era a casa do João Hennemann. Aí eu fui pra ali empregada. Ali eu já fazia outros serviços. Foi o primeiro dono da Ford. João Wendelino Hennemann. Hoje, o Flávio ainda tá casado com uma filha do Arnoldo Hennemann, que era filho do João Wendelino Hennemann, dono da Ford. Aí eu fui passando de um irmão para o outro dos Hennemann.

"Ir passando”, “ser pega” - expressões recorrentes de Vó Nair para falar de sua relação de trabalho no interior de uma mesma família - comunicam a forma como o agregado circulava entre as gerações de uma mesma família, numa sujeição das mulheres negras ao personificado nas aristocracias de origem alemã em Novo Hamburgo, lembrando o que José de Souza Martins (1979, p. 15) aponta para a presença do passado de trabalho escravo na sua condição de trabalho livre. As repercussões disso aparecem na forma como Vó Nair agrupa seletivamente os rastros de suas memórias como "escrava de estimação" à sua condição de mulher negra liberta, concluindo: "eu passei tudo isto aí, mas eu tinha boas lembranças da minha infância, porque no fundo eu era bem tratada".

Contrastando com a dimensão do trabalho livremente vendido no mercado, as lembranças de Vó Nair nos sugerem uma vida de cativeiro (Souza Martins, 1979), uma vez que ao longo de seus 94 anos sua vida esteve de certa forma aprisionada ao monopólio das vontades das famílias abastadas do Vale do Sinos, seguindo uma linhagem de vida dedicada aos outros que foi inaugurada por sua avó e mãe no interior da comunidade alemã de Novo Hamburgo.

O reconhecimento da condição sociológica de cativeiro, entretanto, não reduz a complexidade dos jogos da memória que acompanham a narrativa biográfica de Vó Nair. No espaço fantástico da memória, o tempo presente, associado ao mundo do trabalho livre não se apresenta em oposição ao tempo passado, quase sempre relacionado ao mundo da escravidão. Sob a ótica da consolidação de uma identidade narrativa, Vó Nair não apresenta uma oposição irreconciliável entre as formas de vida dos alemães e a dos negros em Novo Hamburgo. Ao contrário, a afiliação da família de origem de Vó Nair à cultura germânica, o domínio do dialeto alemão transmitido de geração a geração em sua família, o lugar de residência próximo às famílias brancas da aristocracia 
local se entrelaçam dramaticamente com as lembranças da violência física, do abuso e da exploração sofridas por essas gerações de mulheres negras.

Acompanhar, portanto, as transformações do mundo do trabalho na região do Vale do Sinos pelo viés da memória de três gerações de mulheres negras nos permite pensar o mundo alemão como uma unidade simbólica plural, cultural e etnicamente multideterminada. Trazendo à tona a organicidade das camadas de duração que configuram o fenômeno temporal da memória coletiva negra na região em detrimento de uma visão absoluta ou exclusiva do mundo do branco, o do colono alemão. Um fenômeno que não seria possível caso não nos detivéssemos na riqueza dos laços através dos quais Vó Nair, a personagem dessa história, tece, no plano da intratemporalidade (Ricoeur, 1994) e nas diferentes passagens de seu excurso etnobiográfico, o tempo histórico da colonização alemã no Vale do Sinos e o tempo vivido por ela, sua avó e sua mãe ao longo desse processo.

\section{Referências}

AZEVEDO, C. M. M. O negro livre no imaginário das elites. Dissertação. (Mestrado em História)-Instituto de Filosofia e Ciências Humanas, Universidade Estadual de Campinas, Campinas, 1985.

BARROS, M. N. F. Análise psicossocial das representações de empregadas domésticas (estudo exploratório). Dissertação (Mestrado em Psicologia Social)-Pontifícia Universidade Católica de São Paulo, São Paulo, 1985.

CARDOSO, F. H. Capitalismo e escravidão no Brasil meridional: o negro na sociedade escravocrata do Rio Grande do Sul. Rio de Janeiro: Paz e Terra, 1977.

DURAND, G. Les structures anthropologiques de l'Imaginaire. Paris: Dunod, 1984.

ECKERT, C.; ROCHA, A. L. C. da O tempo e a cidade. Porto Alegre: Editora da UFRGS, 2005.

FERNANDES, F. O negro no mundo dos brancos. São Paulo: Global, 2007. 
GIACOMINI, S. M. Mulher e escrava: uma introdução histórica ao estudo da mulher negra no Brasil. Petrópolis: Vozes, 1988.

LIMA RIBEIRO, A. P. A situação da empregada doméstica em São Paulo. Trabalho apresentado à Escola de Serviço Social PUC/SP, São Paulo, 1943.

LIND, V. Africans in early modern German Society: identity - difference aesthetics - anthropology. Bulletin of the German Historical Institute, n. 28, Spring 2001. Disponível em: <http://www.ghi-dc.org/publications/ghipubs/ bu/028/b28lindframe.html>. Acesso em: 20 jul. 2012.

MOREIRA LEITE, M. A condição feminina no Rio de Janeiro, século XIX. São Paulo: Hucitec; Instituto Nacional do Livro; Fundação Nacional PróMemória, 1984.

MÜLLER, T. L. Negros de fala alemã. In. FISCHER, L. A.; GERTZ, R. E. (Coord.). Nós, os teuto-gaúchos. Porto Alegre: Editora da Universidade, 1998. p. 238-239.

NUNES, M. F. O negro no mundo alemão: cidade, memória e ações afirmativas no tempo da globalização. Tese (Doutorado em Antropologia Social)-Centro de Filosofia e Ciências Humanas, Universidade Federal de Santa Catarina, Florianópolis, 2009.

PINTO, E. A. Mulher negra e o emprego doméstico: a travessia pelo século XX e as novas perspectivas para o século XXI. Confederação Nacional dos Trabalhadores em Educação, 6 mar. 2012. Disponível em: <http://www. cnte.org.br/index.php/component/content/article/181-artigos/9790-mulhernegra-e-o-emprego-domestico-a-travessia-pelo-seculo-vinte-e-as-novasperspectivas-para-o-seculo-xxi>. Acesso em: 15 abr. 2012.

PRELORÁN, J. Conceptos éticos e estéticos en cine etnográfico. In: ROSSI, V. El cine documental etnobiográfico de Jorge Prelorán. Buenos Aires: Busqueda, 1987. p. 73-119.

RICOEUR, P. Tempo e narrativa: tomo I. Campinas: Papirus, 1994. 
SAFFIOTI, H. I. B. Emprego doméstico e capitalismo. Rio de Janeiro: Vozes, 1978.

SOUZA, E. M. de O. Emprego doméstico e a questão racial. Trabalho de Conclusão de Curso de Faculdade de Serviço Social da PUC/SP, São Paulo, 1982.

SOUZA MARTINS, J. O cativeiro da terra. São Paulo: Ciências Humanas, 1979.

TRAMONTINI, M. J. A escravidão na colônia alemã (São Leopoldo - primeira metade do século XIX). In: PRIMEIRAS JORNADAS DE HISTÓRIA COMPARADA, 2000, Porto Alegre. Anais... Porto Alegre: Fundação de Economia e Estatística, 2000. Disponível em: <http://www.fee.com.br/sitefee/ download/jornadas/1/s5a3.pdf > . Acesso em: 15 fev. 2012.

TRAMONTINI, M. J. A Colônia de São Leopoldo: a organização social dos imigrantes na fase pioneira (1824-1850). Tese (Doutorado em História)Pontifícia Universidade Católica do Rio Grande do Sul, Porto Alegre, 1997.

VIEIRA, C. R. Negra, mulher e doméstica. Considerações sobre as relações sociais no emprego doméstico. Estudos Afro-Asiáticos, n. 14, p. 141-158, 1987.

ZUBARAN, M. A. Os teuto-rio-grandenses, a escravidão e as alforrias. In: MAUCH, C.; VASCONCELOS, N. (Org.). Alemães no Sul do Brasil. Canoas: Editora Ulbra, 1994. p. 65-74. 